\section{IN MEMORIAM OF ICHTHYOLOGIST AND SCIENTIST SAULIUS STAKE்NAS}

\author{
„Nežinai dienos, nei valandos, \\ Nežinai, širdis kada sustos.
}

Vilčių lauželị kūreni - gy-ve-ni.“

(Lines about fragility of life from an old notebook of Lithuanian writer Vytautas Bubnys)

On 16 November 2021, Nature Research Centre's community suffered a loss of a colleague, ichthyologist, doctor of biomedical sciences Saulius Stakenas. Saulius was born in Vilnius on 6 November 1971. Upon graduation from secondary school, he studied biology at the Faculty of Natural Sciences of Vilnius University. Still a student, Saulius "opened the door" of the Institute of Ecology of Vilnius University.

His early scientific career started at the Sector of Freshwater Ecology of the Laboratory of Fish Ecology and Physiology. At that particular time, Sector's researchers were focused on ecosystems and reproduction processes of ichthyofauna in Lithuanian rivers. Saulius was offered a new and responsible research trend, i.e. investigation of juvenile fish populations and communities in rivers. As young-of-the-year (age $0+$ ) fish had poorly been studied in Lithuanian rivers, this new trend attracted attention and gained recognition. Saulius actively participated in expeditions organised by the laboratory to many Lithuanian rivers and with great care and scrutiny was collecting research material. Having generalised the collected research data, Saulius Stakenas prepared his graduation thesis and successfully graduated from Vilnius University in 1995.

Saulius' interest in fish and related scientific research did not wane, and after graduation he started working as an assistant at the Institute of Ecology. In 1998, Saulius took up his doctoral studies, and in 2002 successfully defended his doctoral dissertation "Habitat Selection Strategy of 0+ Fish in the Rivers of Lithuania" (scientific supervisor Prof. Dr habil. Juozas Virbickas). In his

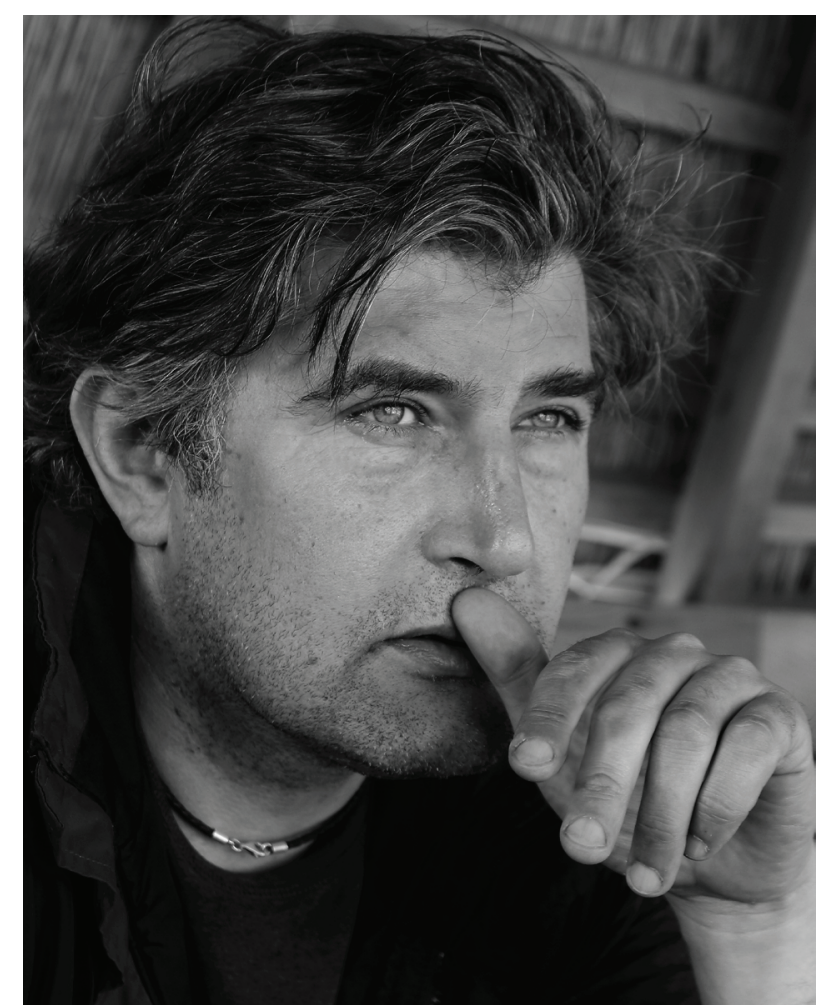

dissertation, Saulius revealed that from the viewpoint of time and space the young-of-the-year constitute the stage of fish life cycle which is highly dependent on environmental variables. The living environment of $0+$ fish is narrow and specific; therefore, environmental variables induce greater changes in the abundance, species diversity and community structure of $0+$ fish compared to adult fish. This shows the importance of relationship between $0+$ fish and the environment when studying the stability and the state of river ecosystems. From a scientific viewpoint, the dissertation is highly significant for investigation of fish populations, communities and their functioning regularities, and in a broad sense it is important for investigating fish reproduction processes in river ecosystems.

After defence of his doctoral dissertation, Saulius continued working as a researcher at the Laboratory of Ecology and Physiology of Hydrobionts of the Institute of Ecology, and in 2004 he moved to work as a researcher at the Centre for Environment, Fisheries and Aquaculture Science (CEFAS) in the United Kingdom under the EU programme Marie Skłodowska-Curie Actions. In the UK, Saulius Stakenas mastered a new and very important method of telemetric investigation of fish migrations, which was later introduced in Lithuania.

Dr Saulius Stakenas deserves to be considered the pioneer of application of telemetry method in Lithuania. Saulius came back from the UK in 2006 and took the position of Senior Researcher at the Laboratory of Ecology and Physiology of Hydrobionts of the Institute of Ecology. First telemetric investigations in Lithuania 
were started within the programme for restoration and abundance increase of salmon and sea trout. Later, the method was applied to other scientific investigations, such as identification and determination of the value of fish spawning sites, investigation and monitoring of fish passage efficiency, assessment of interspecific fish competition, habitat selection in fish, mortality of restored fish populations (due to predation, fishing and natural deaths), anthropogenic impact on fish migration and behaviour, etc. Radio frequency identification tags and acoustic telemetry were for the first time used for salmon and sea trout in the fish passage at the Valtunai HPP on the Siesartis River. Later, the efficiency of fish passages was evaluated on the Vilnia River during autumnal migration of salmon, with the measures to enhance fish passage efficiency offered. Conventional and radio tagging was used to investigate not only migrating fishes (salmon, sea trout, eel) but also rare species (Atlantic sturgeon) and their living places in the Nemunas basin, Curonian Lagoon and Baltic Sea.

The scope of Saulius' scientific interests was always expanding: he was interested in ichthyology, fisheries, ecology, environmental protection, and was a consultant on fish passages, hydropower plant impacts, and elimination of dams. He was a scientific supervisor of students attaining master's or doctoral degrees. He headed more than 20 different projects and participated in over 60 national and world-wide projects. Dr S. Stakenas was a recognised expert on the issues of the management and restoration of European eel, Atlantic salmon, sea trout and Atlantic sturgeon stocks. S. Stakenas announced or was a co-author of more than 30 peer-reviewed scientific articles and wrote multiple popular science publications.

We will always share good and warm words about Saulius. Only death awakens our feelings, how we treasure the person who has just passed away, with whom we haven't talked about so many things, haven't finished so much work, or simply haven't travelled round the world, as Saulius liked. All that is left for us is his scientific works, ideas and memories of Saulius as a cheerful, diligent and full of enthusiasm man, a real patriot of Lithuania. 